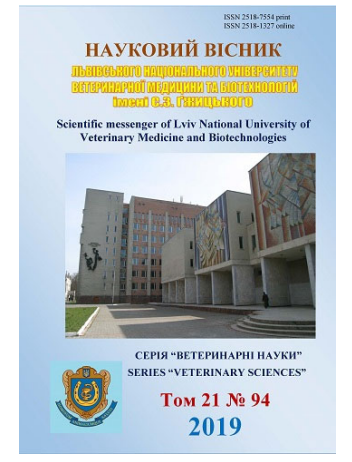

Науковий вісник Дьвівського національного університету ветеринарної медицини та біотехнологій імені С.3. Гжицького.

\author{
Серія: Ветеринарні науки
}

Scientific Messenger of Lviv National University of Veterinary Medicine and Biotechnologies. Series: Veterinary sciences

\title{
The influence of prophylactic biopreparations on preservation and microbiocenosis of chickens
}

\author{
M.D. Kucheruk, D.A. Zasekin \\ National University of Life and Environmental Science of Ukraine, Kyiv, Ukraine
}

Article info

Received 26.03.2019

Received in revised form 26.04.2019

Accepted 29.04.2019

National University of Life and Environmental Sciences of Ukraine, Heroyiv Oborony Str., 15, Kyiv, 03041, Ukraine.

Tel: +38-066-245-80-34

E-mail: kucheruk_md@nubip.edu.ua
Kucheruk, M.D., \& Zasekin, D.A. (2019). The influence of prophylactic biopreparations on preservation and microbiocenosis of chickens. Scientific Messenger of Lviv National University of Veterinary Medicine and Biotechnologies. Series: Veterinary sciences, 21(94), 44-50. doi: $10.32718 /$ nvlvet 9408

The cultivation of organic birds is an important stage in ensuring the population, in particular children, a source of quality and easily digestible protein. The use of antibiotics with a prophylactic purpose in organic livestock is prohibited at the legislative level. Therefore, this new direction in agriculture requires professional scientific support and effective natural prophylaxis as an alternative to antibiotics. The research was conducted in a certified organic poultry farm. The purpose of the production trial of the probiotic and the new postbiotic drug on chickens was to compare their effectiveness with respect to the productivity and consistency of the poultry. The results were compared with the data of the control group of chickens and experimental groups among themselves. In addition, there was a link between the performance of chickens with the functional state of intestinal microbiocenosis and the corrective effect of these drugs. The expressed prophylactic effect of the tested drugs on the best of 20-22\% preservation of chickens, as well as on higher body weight gain was established. The death of the control group chickens was due to dysbiosis of digestion with the domination of E. coli in the intestine. The study of intestinal microbiocenosis showed significantly higher concentrations of lactobacillus in the chickens of both experimental groups compared with the control group. Due to the competitive substitution of lactobacilli, the amount of E. coli in the intestines of chickens in experimental groups was reduced, where the test drugs were used. Excessive E. coli in the intestines of the control group chickens could provoke inflammation in the intestine and the development of clinical manifestations of colibacillosis. As a consequence - recorded a high percentage of deaths of chickens in this group. Thus, correction of microendocology of poultry intestines may be carried out by prophylactic preparations based on living representatives of symbiotic microflora (probiotics) or compositions of their useful metabolites (postbiotics). Such a correction occurs naturally, without violating the traditional mechanisms of interaction within the microbiological pool.

Key words: organic poultry, probiotics, postbiotics, preventive, chicken.

\section{Вплив профілактичних біопрепаратів на збереженість та мікробіоценоз кишечнику курчат}

\author{
М.Д. Кучерук, Д.А. Засєкін
}

Національний університет біоресурсів і природокористування Украӥни, м. Киӥв, Украӥна

Вирощування органічної птиці є важливим етапом забезпечення населення, зокрема дітей, джерелом якісного й легкозасвоюваного протеїну. Використання антибіотиків із профілактичною метою в органічному тваринництві заборонено на законодавчому рівні. Тому цьому новому напряму сільського господарства потрібен фаховий науковий супровід та ефективні натуральні профілактичні препарати як альтернатива антибіотикам. Дослідження проводилися в сертифікованому органічному птахогосподарстві. Метою виробничого випробування пробіотика й нового препарату постбіотика на курчатах було порівняння їхньої ефективності щуодо продуктивності та збереженості птиці. Порівнювали отримані результати з даними контрольної групи курчат 
й дослідних груп між собою. Крім того, відзначали зв'язок показників продуктивності курчат із функиіональним станом мікробіоценозу кишечнику та корегувальним впливом вказаних препаратів. Встановлено виражену профілактичну дію випробовуваних препаратів щчодо кращсї на 20-22\% збереженості курчат, а також на вищі прирости маси тіла. Загибель курчат контрольної групи відбувалась внаслідок дисбіотичних розладів травлення з домінуванням Е. софі в кишечнику. Дослідження мікробіоценозу кишечнику показали достовірно вищі концентрації лактобактерій у курчат обох дослідних груп порівняно з контрольною. За рахунок конкурентного замімення лактобактеріями було зменшено кількість Е. солі в кишечнику курчат дослідних груп, де застосовувались випробовувані препарати. Надмірна кількість Е. coli в кишечнику курчат контрольної групи могла спровокувати виникнення запальних процесів у кишечнику и розвиток клінічних проявів колібактеріозу. Як наслідок - фіксували високий відсоток загибелі курчат цієї групи. Отже, корекцію мікроендоекологї кишечнику птиці можливо здійснювати профілактичними препаратами на основі живих представників симбіотичної мікрофлори (пробіотиками) чи композицій їх корисних метаболітів (постбіотиками). Така корекція відбувається природним иляхом, не порушуючи традиційні механізми взаємодї всередині мікробіологічного пулу.

Ключові слова: органічна птиця, курчата, пробіотики, постбіотики, профілактика.

\section{Вступ}

Для вирощування органічної птиці, особливо в умовах великих птахогосподарств, досить складним $€$ питання профілактування хвороб на фоні заборони використання профілактичних антибіотиків. Через це фермери переживають економічні втрати внаслідок значної загибелі молодняку птиці. Продуктивність тварин залежить також від низки санітарногігієнічних та зоотехнічних показників: способу утримання, розміру груп, щільності посадки, мікроклімату приміщень та від організації вчасної і збалансованої годівлі. За кожним зоогігієнічним параметром встановлені певні діапазони їхніх значень, за яких тварини витрачають мінімальну кількість енергії для підтримки фізіологічних процесів на оптимальному рівні (Cicenia et al., 2013). Якщо ж норми утримання порушуються - виникають стресові ситуації, за яких знижується загальна резистентність організму та його опірність до збудників хвороб, погіршується апетит та зменшується засвоюваність кормів, виникають розлади органів травлення, втрачаються прирости маси тіла, збільшується конверсія корму та падіж (Crandall et al., 2009, Kucheruk et al., 2017).

Аналіз останніх досліджень та публікаџій. Мікрофлора травного каналу відіграє важливу роль в імунному статусі та загальному метаболізмі макроорганізму. Завдяки цілому ряду функцій, які вона виконує, порожнинна та пристінкова мікрофлора відіграє роль захисного бар'єру на шляху проникнення різних інфекційних агентів в організм господаря. Зазвичай на фоні стресової ситуації відбувається порушення адаптаційних можливостей організму. I тоді численні представники умовно-патогенної мікрофлори (колібактерії, сальмонели) здатні викликати асоційовані епізоотичні процеси (Gabriel, 2005, Harda et al., 2014).

Для позначення мікрофлори здорового організму використовують різноманітні терміни: аутомікрофлора, нормальна мікрофлора (нормофлора) або просто мікрофлора організму, мікробіота, нормомікробіоцено3, еубіоз.

Пробіотики здатні відновлювати мікробний баланс, пригнічувати патогенні мікроорганізми, поліпшувати безпечність тваринницької продукції (Zinchenko et al., 2003). У разі зменшення у травному каналі лактофлори у птиці знижується здатність до знешкодження харчових токсинів, порушуються процеси регуляції ферментативного, гормонального, ві- тамінного і мінерального обмінів, що зумовлює імунодефіцитний їх стан (Balamatsia et al., 2007). За зниження імунітету ентеробактерії часто призводять до зміни функції кишечнику, формування запальних процесів у різних органах за впливу мікробних токсинів (Dal Bosco et al., 2016).

Механізм дії пробіотиків полягає в їхній здатності активно заселяти шлунково-кишковий тракт, виробляти біологічно активні метаболіти, що забезпечують ïх виживання в боротьбі з патогенами, в їхній стійкості до дії шлункового соку та жовчі. Крім того, завдяки своїм ферментативним властивостям симбіотична мікрофлора бере участь у переробці значної кількості органічних речовин, синтезує білки, поліпептиди, амінокислоти, антибіотики, вітаміни та інші цінні метаболіти (Cicenia et al., 2013).

Постбіотики - препарати на основі метаблоітів симбіотичних мікроорганізмів, які володіють вираженою бактерицидною дією проти багатьох патогенних мікроорганізмів, що утворюються при бактеріальній ферментації. Вони здатні модулювати імунну відповідь організму. Представниками метаболітів симбіотичних бактерій, що виконують бактерицидну функцію в кишечнику є бактеріоцини та органічні кислоти (Kumar et al., 2019) Багато представників грамнегативних і грампозитивних бактерій (особливо лактобактерії) продукують антибіотичні речовини білкової природи - бактеріоцини. Механізм біологічної дії бактеріоцинів пов'язаний, насамперед 3 порушенням цитоплазматичних мембран чутливих до них мікроорганізмів. Бактеріоцини на відміну від антибіотиків, що діють досить вибірково, впливають і на резистентні до антибіотиків штами мікроорганізмів, повністю розщеплюються і виводяться 3 організму. Імовірність накопичення та виникнення ускладнень від бактеріоцинів - мінімальна (Udo et al., 2006; Hilmi et al., 2019; Macer, 2019).

Метою дослідження проведених досліджень було вивчення ефективності пробіотика й розробленого нами постбіотика та оцінки їхнього впливу на збереженість та продуктивність курчат, з'ясування їхньої профілактичної дії внаслідок корекції мікробіоценозу травного каналу. Виробниче випробування та впровадження їх в органічному виробництві становлять науковий та практичний інтерес. 


\section{Матеріал і методи досліджень}

Вирощування птиці проводилось у сертифікованому органічному птахівничому господарстві Житомирської області. Методом аналогів було сформовано три групи курчат породи "Кучинська ювілейна", м'ясо-яєчного напряму продуктивності.

$\mathrm{y}$ першому приміщенні пташника утримувалась дослідна група курчат, їм згодовували органічний корм та додавали у воду пробіотик на основі Lactobacillus plantarum у таких пропорціях: 1 мг/л води протягом тижня з інтервалом 7 діб.

У другому - також дослідна група курчата, якій згодовували органічний корм та обробляли його аерозолем водного розчину постбіотика "Бактеріосан", (розчин суміші 4\% молочної кислоти і бактеріоцина Нізина) в кількості 0,05 г/кг корму, для обробки використовували мілкодисперсний ручний генератор холодного туману.

У третьому - курчата контрольної групи, які отримували органічний корм.

Відбір проб із кишечника курчат здійснювали на 30, 90, та 160 добу досліду, по 3 проби від курчат із кожної групи. Визначення складу мікрофлори травного каналу курчат проводили в акредитованій лабораторії "Українська лабораторія якості й безпеки продукції АПК”. Підготовку досліджуваних проб та виявлення мікроорганізмів проводили за відомими стандартними методиками.

Для взяття проб для мікробіологічних досліджень відбирали тонкий відділ кишечнику, без дванадцятипалої кишки. Суспензували з додаванням ізотонічного розчину, струшували в апараті “Шутель” протягом 10 хв і давали настоятись іще 10 хв. Висівали на поживні середовища. Визначали вміст показових мікроорганізмів за спрощеною схемою. Визначали кількість молочнокислих мікроорганізмів, коагулазопозитивних Staphylococcus aureus, сальмонел та ентеробактерій.

Підготовка проб для визначення коагулазопозитивних Staphylococcus aureus - згідно з ДСТУ ISO 6887-1:2003 Мікробіологія харчових продуктів та кормів для тварин. Підготовку досліджуваних проб, вихідної суспензії та десятикратних розведень для мікробіологічного досліджування. Частина 1. Загальні правила готування вихідної суспензії та десятикратних розведень (ISO 6887-1:1999, IDT). Виявлення коагулазо-позитивних Staphylococcus aureus - згідно 3 ДСТУ ISO 6888-1:2003 Мікробіологія харчових продуктів і кормів для тварин. Горизонтальний метод підрахування коагулазо-позитивних стафілококів. Частина 1. Метод 3 використовуванням агарового середовища Беард-Паркера (ISO 6888-1:1999, IDT). Визначення кількості молочнокислих мікроорганізмів - згідно з ГОСТ 104444.11-2013 (ISO 15214:1998) Микробиология пищевых продуктов и кормов для животных. Методы выявления и подсчета мезофильных молочнокислых микроорганизмов. Підготовка проб та виявлення сальмонел (Salmonella) та ентеробактерій (Enterobacteriaceae) - згідно з МУ 4.2.2723-10
“Лабораторная диагностика сальмонеллезов, обнаружение сальмонелл в пищевых продуктах и объектах окружающей среды”, 2010; МУ “Лабораторная диагностика сальмонеллезов человека и животных, обнаружение сальмонелл в кормах, продуктах питания и объектах внешней среды" - 1990 г; МУ "Микробиологическая диагностика заболеваний, вызываемых энтеробактериями”, 1984. В експерименті також враховували показники збереженості поголів'я. Фіксувалися всі випадки загибелі курчат 3 встановленням причини та виділенням збудника. Продукція, отримана в результаті проведення досліду, не реалізовувалась як органічна. Однак препарати, які себе добре зарекомендували, господарство в подальшому впроваджувало при вирощуванні органічної птиці.

\section{Результати досліджень}

Продуктивність та збереженість птиці $є$ дуже важливим показником, зрушення якого свідчить про зміни в організмі - бажані чи небажані. Показники продуктивності курчат на кінець досліду були не досить високими, проте для органічного екстенсивного виробництва - прийнятними. Курчата м'ясо-яєчної породи в добовому віці важать у середньому на 10 г менше, ніж курчата-бройлери (33-34 г проти 45 г відповідно). На 180 добу вирощування жива маса курчат у контрольній групі становила в середньому 1567 г. У першій та другій дослідній групах птиці - відповідно 1926 г та 1993 г.

Збереженість поголів'я також була не $100 \%$. Пов'язано це, на наше переконання, 3 недостатнім виконанням санітарно-гігієнічних заходів та проникненням і розповсюдженням патогенних мікроорганізмів, що створювали негативний мікробний фон і знижували імунітет птиці. У господарстві не було вжито всіх належних санітарно-гігієнічних заходів щодо запобігання потраплянню інфекційних агентів та належного облаштування території пташників. Так, не було суцільної огорожі навколо пташників, що давало можливість проникнення на територію господарства диким і домашнім тваринам і птиці; відсутнє централізоване водопостачання у пташниках, не облаштований дезбар'єр на в'їзді в господарство, немає санпропускника, а також змінного робочого одягу.

Зважаючи на те, що профілактичні препарати випробовувались у таких “екстремальних” умовах, вони в достатній мірі проявили свою ефективність.

Загибель молодняку птиці часто значною мірою зумовлена недорозвиненістю та несформованістю мікробіологічного пулу кишечнику, а отже й відсутністю належної імунобіологічної відповіді на проникнення патогенної мікрофлори.

Тому найважливішим завданням для отримання здорового поголів'я сільськогосподарської птиці $\epsilon$ забезпечення швидкого і повноцінного формування складу мікрофлори травного тракту в молодняку.

Органічне ведення птахівництва за організацією відрізняється від такого з використанням інтенсивних технологій не лише якісною годівлею, а й особливос- 
тями утримання на відкритих вигульних майданчиках. Однак разом із користю від інсоляції та зміцнення імунітету таке утримання пов'язане 3 певними ризиками (Hadzalo \& Kaminskyi, 2016).

За аналізом клінічних показників стану курчат та їх зовнішнього вигляду, жвавості, апетиту, можна зробити висновок про відносну стабільність внутрішнього гомеостазу курчат всіх дослідних груп.

Найвищу загибель курчат реєстрували в контрольній групі. Загибель курчат дослідних груп була епізодичною й не мала чітко визначеної залежності. У контрольній групі фіксували падіж курчат без певної закономірності, пов'язаний, на нашу думку, із наявністю та неконтрольованим розмноженням бактерій групи кишкової палички. В інших групах курчат, де застосовувались профілактичні препарати, відбувалось направлене корегування мікробіоценозу кишечнику (табл. 1).

\section{Таблиця 1}

Збереженість поголів'я, \%

\begin{tabular}{lccc}
\hline \multirow{2}{*}{ Показник } & \multicolumn{3}{c}{ Групи курчат } \\
\cline { 2 - 4 } & Д1 & Д2 & Контроль \\
\hline Загибель птиці у групі & 12 & 10 & 32 \\
Збереженість & 88 & 90 & 68 \\
\hline
\end{tabular}

Порівняно 3 контрольною групою, де загальний падіж (за весь період вирощування) становив 32\%, у групі, де 3 кормом застосовували розроблений нами профілактичний препарат постбіотик "Бактеріосан" (Д2), було досягнуто показнику збереженості 90\%. Досить високий показник збереженості птиці виявлено також серед курчат першої дослідної групи (Д1) 88 \%. Для органічного виробництва це є задовільним результатом, оскільки в цьому ж господарстві у попередні цикли вирощування курей падіж досягав 80\%.

У деяких курчат, які гинули в наступні періоди, спостерігалась діарея протягом 2-3 діб, у інших пригнічений стан, опущені крила, скуйовджений пір'яний покрив, зниження апетиту та, як наслідок, зниження продуктивності (відсутність приростів маси тіла).

Із трупів курчат, що були відправлені до лаборатоpiї, окрім кишкової палички, не було виділено ні стафілококу, ні сальмонели. Також паразитологічними дослідженнями було виключено зараження курчат еймерією (eimeriosis). За результатами проведених клінічних та мікробіологічних досліджень можна стверджувати, що латентний перебіг захворювання молодняку та загибель курчат спровокували дисбіотичні явища в кишечнику курчат, оскільки кишкова паличка, що у значних концентраціях була виділена 3 кишечнику птиці, могла мати ентеропатогенні властивості.

Більшість серотипів E. coli, виділених від домашньої птиці, є патогенними тільки для птиці й не викликають розвиток хвороб у інших тварин і людини. Однак кожен серовар кишкової палички включає в себе вірулентні та авірулентні штами, ідентифікацію збудників сільськогосподарської птиці найчастіше проводять за ознаками клінічних проявів колібактеріозу.

Із другої дослідної групи з 1 до 10 доби загинуло двоє курчат. Одне внаслідок травмування, інше було вибракуване через вроджену патологію кінцівок та неможливість належно рухатись і харчуватись.

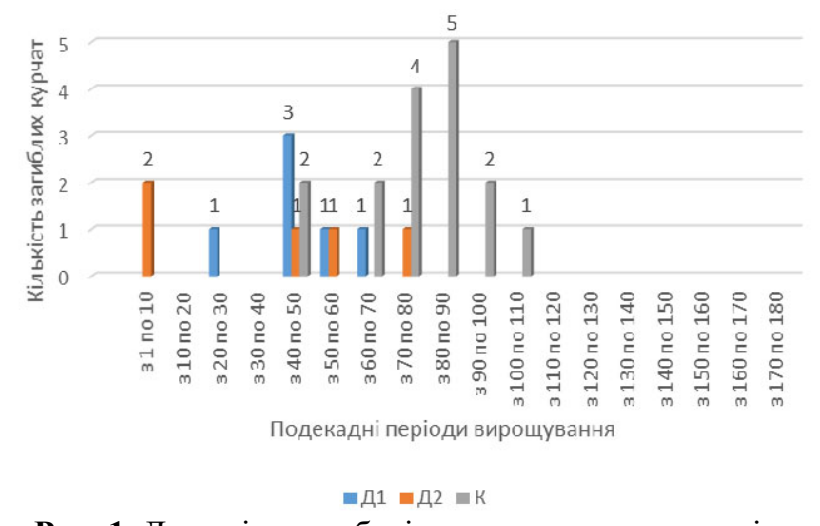

Рис. 1. Динаміка загибелі курчат впродовж досліду

Із першої дослідної групи з 20 до 30 доби загинуло лише одне курча. Однак надалі спостерігалось різке підвищення кількості загиблих курчат у період з 40 до 50 доби, що склало 6\%. Ймовірною причиною того, що пробіотичний препарат не реалізував свою потенційну профілактичну дію стало недостатнє дотримання персоналом санітарно-гігієнічних правил під час обслуговування пташників та похибки в технології приготування, зберігання та випоювання пробіотика.

Найбільший падіж серед птиці у контрольній групі був зафіксований у період з 70 до 90 доби вирощування. Клінічно захворювання проявлялося діареєю, слабкістю, уповільненою реакцією на зовнішні подразники, відсутністю апетиту, в одному випадку загибель курчати супроводжувалась нервовими явищами. Температура тіла була підвищена на $1,3{ }^{\circ} \mathrm{C}$. Виражених патологоанатомічних змін у внутрішніх органах не виявляли, окрім незначної гіперемії кишечника. Однак було відмічено, що тяжкість перебігу колібактеріозу й супутніх бактеріальних кишечних інфекцій птиці залежить від їх природної резистентності організму. За допомогою проведених лабораторних мікробіологічних досліджень вдалося виділити кишкову паличку з різних органів і тканин курчат контрольної групи.

У окремих випадках патологоанатомічний розтин трупів курчат 3 контрольної групи фіксував явища катарально-геморагічного ентериту. Кишечник розтягнутий внаслідок переповнення рідкими фекаліями 3 домішками газу і слизу. У кількох трупів фіксували застійну гіперемію печінки (збільшена, темно-бурого кольору). Епітелій та слизова оболонка тонкого відділу кишечнику майже до клоаки курчат гіперемійована й набрякла.

Відповідно до постанови Кабінету Міністрів України "Про затвердження Порядку (детальних правил) органічного виробництва та обігу органічної продукції”, розділ III, п. 59-62 у випадку, якщо незважаючи на профілактичні заходи, спрямовані на забезпечення 
здоров'я тварин, тварини захворіли необхідно негайно розпочати їх лікування та в разі потреби ізолювати. Під час лікування тварин необхідно віддавати перевагу застосуванню фітотерапевтичних, гомеопатичних препаратів, мікроелементів та речовин, що входять до Переліку речовин (інгредієнтів, компонентів), які дозволяється використовувати у процесі органічного виробництва та які дозволені до використання у гранично допустимих кількостях, перед лікуванням хімічними алопатичними ветеринарними препаратами або антибіотиками, за умови, що перші $є$ ефективними для лікування тварин даного виду і для даного випадку. У разі використання ветеринарних препаратів необхідно дотримуватися періоду його виведення відповідно до настанови з використання та збільшити час очікування у 2 рази, або на 48 годин, якщо такий період не зазначений.

Підвищена загибель курчат у контрольній групі тривала від 40 до 110 доби вирощування. Оскільки вирощування курчат проводилось в рамках науководослідного експерименту, лікувальні або профілактичні препарати у цій групі тварин не застосовувались. Однак варто відзначити, що до 160 доби вирощування кури подолали цей патоген, виробивши до нього імунітет природнім шляхом. Після 110 доби експерименту загибелі курчат в контрольній групі більше не фіксували.

Кількісні та якісні зміни і будь-які зрушення співвідношень між облігатною та факультативною мікрофлорою травного каналу птиці та окремих їх асоціацій спричинюють зміну складу й кількісних показників мікробних ензимів, що порушує процес травлення: спочатку порушується розщеплення полісахаридів, а потім і протеїнів та жирів. У результаті цього в кишечнику птиці посилюється газоутворення та починаються процеси бродіння і гниття, що призводить до токсичного отруєння організму загалом (Kalmykova, 2001). Основними причинами погіршення процесів травлення $є$ ушкодження поверхні кишечнику парази- тами та бактеріями, як наслідок - збільшується тривалість перебування корму в шлунково-кишковому тракті птиці та відповідно посилюється розмноження у кишечнику мікроорганізмів умовно-патогенних та патогенних видів. Провідну роль у захисті від патогенів відіграє пристінкова симбіотична мікрофлора, зокрема молочнокислі мікроорганізми

Завдяки механізму конкурентного витіснення лактобактерії не дають можливості прикріплятися до стінки кишечнику умовно-патогенним та транзиторним мікроорганізмам.

Випробувані препарати (пробіотичний препарат та розроблений нами постбіотик “Бактеріосан”) створювали в кишечнику курчат “захисний бар'єр”: пробіотик - за допомогою постійного надходження нових колонієутворюючих одиниць із смибіотичних мікроорганізмів, представників лактобактерій, а постбіотик - за рахунок підкислення внутрішнього середовища та бактерицидної цілеспрямованої дії на штами мікроорганізмів-конкурентів лактобактерій.

У кишечнику курчат першої дослідної групи найвищою була кількість лактобактерій упродовж усього періоду досліду (табл. 2). На 30 добу експерименту титр лактобактерій у травному каналі курчат із дослідних груп був значно вищий, ніж у контрольні. Крім того, із проб шлунка та кишечнику курчат контрольної групи було виділено Escherichia coli, оскільки це надзвичайно розповсюджений збудник, що провокує високий рівень захворюваності.

У кишечнику курчат із другої дослідної групи дещо нижчою була кількість лактобактерій порівняно 3 аналогічним показником у курчат першої дослідної групи, однак реєстрували досить високі титри лактобактерій порівняно 3 контрольною групою. Незначне зниження до рівня 6,23 lg, КУО/г відбулося лише на 90 добу вирощування курчат за одночасного підвищення кількості й БГКП у кишечнику курчат цієї групи.

\section{Таблиця 2}

Кількість молочнокислих бактерій у кишечнику курчат $\operatorname{Lg}, \mathrm{KУO} / г \mathrm{M} \pm \mathrm{m}, \mathrm{n}=3$

\begin{tabular}{cccc}
\hline \multirow{2}{*}{ Групи курчат } & \multicolumn{3}{c}{ Доба вирощування } \\
\cline { 2 - 4 } & 30 & 80 & $8,54 \pm 0,71$ \\
Д1 & $8,86 \pm 0,64$ & $6,47 \pm 0,14$ & $7,47 \pm 0,51$ \\
Д2 & $7,84 \pm 0,43$ & $5,23 \pm 0,29$ & $4,39 \pm 0,19$ \\
К & $4,86 \pm 0,37$ & $5,36 \pm 0,32$ & \\
\hline
\end{tabular}

Близько 99\% від загальної кількості мікроорганізмів сліпої чи товстої кишок різних видів птиці становлять біфідо- та лактобактерії (Zinchenko et al., 2003). Тому виділення $з$ муцинового шару товстого кишечнику курчат мікроорганізмів роду Enterobacteriaceae, зокрема за наявності клінічних ознак дисбактеріозу, свідчить про ентеропатогенні властивості виділеного штаму Escherichia coli та продукування ним Шігатоксину, що не схиляє до сприятливого прогнозу перебігу захворювання.

На 30 добу життя Escherichia coli було виділено лише із вмісту шлунка та кишечнику курчат контро- льної групи. На 90 добу досліджень в усіх групах реєстрували присутність Escherichia coli за одночасного зменшення кількості молочнокислих бактерій, що узгоджується з результатами вітчизняних та зарубіжних авторів. Так, в організмі птиці існують імунодепресивні періоди, які у постембріогенезі курчатбройлерів припадають на: 3-5, 12-20 та 42-45 доби. Концентрація лакто- і біфідобактерій, кількість яких у кишечнику курчат найбільша, до 28 доби зменшується.

Нормальна мікрофлора птиці виконує захисну функцію, оскільки колонізується на приепітеліальній 
кишковій зоні, активно конкурує за джерела живлення, має ширший набір ензимів, а також синтезує низку екзометаболітів, що чинять антагоністичну дію на патогенні і умовно патогенні транзиторні мікроорганізми.

Разом із тим визначення щодо фізіологічної норми стосуються лише якісного складу представників мікробіоценозу конкретного пулу. Щодо кількісного складу певних видів мікроорганізмів, то це питання виключно індивідуальне для кожного макроорганізму.

Однак, маючи узагальнені дані за дослідними групами птиці, можна прослідкувати певні закономірнос- ті. Щодо групи курчат, які отримували пробіотичний препарат, у перший період після виведення відбулася активна колонізація травного каналу лактобактеріями, про що свідчить їх концентрація в кишечнику на рівні $1,4 \times 10^{9}$. Надалі внаслідок фізіологічних змін у макроорганізмі відбулося поступове зниження їхньої кількості, але титри молочнокислих мікроорганізмів, виділених від курчат цієї групи, були найвищими i стабільними порівняно з контрольною та другою дослідною групами. На 90 та 160 добу досліду їх кількість реєстрували на рівні 2,7-4,9 х 107.

\section{Таблиця 3}

Кількість бактерій групи кишкової палички в кишечнику курчат $\mathrm{Lg}, \mathrm{KУO} / г, \mathrm{M} \pm$ m, n = 3

\begin{tabular}{cccc}
\hline \multirow{2}{*}{ Групи } & \multicolumn{3}{c}{ Доба вирощування } \\
\cline { 2 - 4 } & 30 & 90 & $4,01 \pm 0,61$ \\
Д1 & $3,94 \pm 0,54$ & $4,14 \pm 0,56$ & $4,36 \pm 0,16$ \\
Д2 & $3,34 \pm 0,03$ & $4,58 \pm 0,07$ & $5,47 \pm 1,14$ \\
К & $5,96 \pm 0,32$ & $5,95 \pm 0,09$ & \\
\hline
\end{tabular}

Оскільки найнижчі титри лактобактерій фіксували у контрольній групі, відповідно й рівень природної резистентності та імунного захисту курчат цієї групи був найнижчим. Це відобразилося на показниках їхньої продуктивності й збереженості.

Основна складність у визначенні роду збудника полягає в необхідності диференціювати кишкові палички-збудники хвороби, по-перше від інших представників сімейства ентеробактерій, по-друге - від непатогенних E. coli.

Всі бактерії роду Esherihia близькі за культуральними, біохімічними властивостями, проте вони відрізняються за здатністю утворювати індол, зброджувати цукри. Патогенні і непатогенні різновиди E. coli за морфологічними i ферментативним властивостями також не відрізняються один від одного. Пошук патогенних сероварів у досліджуваному матеріалі найчастіше відбувається на тлі рясного росту банальних $E$. coli, що ускладнює виділення та ідентифікацію збудників ешерихіозів.

Для ідентифікації збудника, після проведення первинних посівів на середовище Ендо з патологічного матеріалу (серця, печінки, шлунку, кишечника) на агар Ендо й термостатування за $37^{\circ} \mathrm{C}$ протягом 18-24 год., із чашок Петрі з культурами відбирали типові для ешерихій колонії: круглі з гладкою, опуклою поверхнею рівними краями, діаметром 2-4 мм, червономалинового кольору з металевим блиском.

3 відібраних колоній готували мазки, фарбували їх за Грамом і мікроскопували. В усіх мазках виявили грамнегативні палички із закругленими кінцями, без спор, розташування поодиноке і попарне. Це дозволяє зробити висновок про видову приналежність виділених мікроорганізмів до родини Enterobacteriaceae, роду Escherichia, виду - Escherichia coli. Подальшу родову ідентифікацію й вивчення ферментативних властивостей не проводили.
На 90 добу досліду Escherichia coli була виділена 3 проб кишечнику курчат всіх груп, в різних концентраціях, за досить високих титрів лактобактерій у дослідних групах порівняно 3 контролем. Саме цей факт, на нашу думку, сприяв належній імунній відповіді організму на проникнення патогенів, блокуванню прикріплення та розмноження E. coli в епітелії кишечнику, відсутності клінічно-хворих курчат та гарній їх збереженості.

\section{Обговорення}

Після переведення розрахунків у логарифм вдалося достовірно встановити збільшення кількості БГКП у контрольній групі, майже до 6,0 порівняно з Д1 та Д2, в яких аналогічний показник не перевищував значень відповідно 3,3 та 3,9 на 30 добу вирощування; до 4,14 та 4,58 - на 90 добу вирощування, а також 4,0 та 4,36 - на 160 добу.

У контрольній групі курчат фіксували відносно стабільний рівень бактерій групи кишкової палички, однак за низької кількості симбіотичних бактерій та домінування кишкової палички можливе виникнення захворювання курчат цієї групи на колібактеріоз й до 110 доби реєстрували загибель молодняку. Високий відсоток загибелі птиці можна пояснити, на нашу думку, також недостатньою імунною відповіддю організму на проникнення патогенів через стінки травного каналу, оскільки кількість молочнокислої мікрофлори була досить низькою й конкурентне витіснення стосувалось не кишкової палички, а молочнокислих бактерій. А оскільки останні беруть участь у посиленні фагоцитарної активності макрофагів, моноцитів i гранулоцитів, збільшенні специфічного $\operatorname{IgA}$, синтезу цитокінів, інтерферону, стимуляції клітинних імунних механізмів - без їх достатньої кількості немає й належної імунної відповіді макроорганізму (Cicenia et al., 2013). 
Припускається, що використання пробіотика i постбіотика обумовлювали не тільки зниження кислотозв'язуючої здатності комбікорму, а й істотно поліпшували розвиток у травному каналі лактобактерій і пригнічували розмноження патогенної i умовнопатогенної мікрофлори. Staphylococcus aureus та Salmonella на 90 та 160 добу у жодній пробі від курчат всіх груп виявлено не було.

\section{Висновки}

Експериментом встановлено, що порівняно $з$ контрольною групою курчат, де діагностували колібактеріоз, збереженість становила лише 68\%, превентивна терапія пробіотичним препаратом на основі штаму Lactobacillus plantarum та розробленим нами постбіотиком “Бактеріосан” дала позитивні результати, підвищивши показник збереженості відповідно на 20 та $22 \%$, склавши між тим відповідно 88 та 90\%. Як показує практика, профілактика завжди є більш економічно вигідною за лікувальну терапію, вона цілком виправдана, оскільки знижує загибель птиці та поліпшує економічні показники виробництва. Разом із тим, вона $\epsilon$ лише ланкою в загальному комплексі ветеринарнопрофілактичних заходів.

Корекцію мікроендоекології кишечнику птиці можливо здійснювати профілактичними препаратами на основі живих представників симбіотичної мікрофлори (пробіотиками) чи композицій їхніх корисних метаболітів (постбіотиками). Така корекція відбувається природним шляхом, не порушуючи традиційних механізмів взаємодії всередині мікробіологічного пулу кишечнику.

\section{References}

Balamatsia, C.C., Patsias, A., Kontominas, M.G., \& Savvaidis, I.N. (2007). Possible role of volatile amines as qualityindicating metabolites in modified atmosphere packaged chicken fillets: correlation with microbiological and sensory attributes. Food Chemistry, 104(4), 1622-1628. doi: 10.1016/j.foodchem.2007.03.013.

Cicenia, A., Scirocco, A., Carabotti, M., Pallotta, L., Marignani, M. \& Severi, C. (2013). Postbiotic activities of Lactobacilli-derived factors. Journal of Clinical Gastroenterology, 48(1), 18-22. doi: 10.1097/MCG.0000000000000231.

Crandall, S.P., Seideman, G.S., Ricke, C.A., \& O'Bryan, A. (2009). Organic poultry: consumer perceptions, opportunities, and regulatory issues. The journal of applied poultry research, 18(4), 795-802. doi: 10.3382/japr.2009-00025.

Dal Bosco, A., Mugnai, C., Mattioli, S., Rosati, A., Ruggeri, S., Ranucci, D., \& Castellini, C. (2016). Transfer of bioactive compounds from pasture to meat in organic free-range chickens. Poultry Science, 95(10), 2464-2471. doi: 10.3382/ps/pev383.

Gabriel, I. (2005). La microflore digestive des volailles: facteurs devariation et consequences pour l'animal. INRAProd. Anim., 18, 309-322. https://prodinra.inra.fr/record/77832.

Hadzalo, Ya.M., \& Kaminskyi, V.F. (2016). Naukovi osnovy vyrobnytstva orhanichnoi produktsii v Ukraini : monohrafiia. Natsionalna akademiia ahrarnykh nauk Ukrainy, Natsionalnyi naukovyi tsentr "Instytut zemlerobstva NAAN". K.: Ahrarna nauka (in Ukrainian).

Harda, S.O., Danylenko, S.H., \& Lytvynov, H.S. (2014). Biotekhnolohichni aspekty analizu mikroflory silskohos-podarskoi ptytsi. Biotechnologia acta, 7(4), 2534. http://nbuv.gov.ua/UJRN/biot_2014_7_4_4 (in Ukrainian).

Hilmi, M., Dolberg, F., \& Clarke, B. (2019). Product and profit from poultry. Second Edition. Publisher: FAO. http://www.fao.org/fileadmin/user_upload/slm_agrono ticias/2012/06-15/Publicacion1.pdf.

Kalmykova, A.I. (2001). Probiotiki: terapiya i profilaktika zabolevanij, ukreplenie zdorov'ya. Novosibirsk (in Russian).

Kucheruk, M.D., Zasiekin, D.A., Dymko, R.O., \& Shcherbyna, O.A. (2017). Sanitarno-hihiienichni umovy utrymannia ptytsi za orhanichnoho vyroshchuvannia yak chynnyk produktyvnosti. Bioresursy i prorodokorystuvannia Ukrainy, 9(5-6), 116-124. http://journals.nubip.edu.ua/index.php/Bio/article/vie w/9605 (in Ukrainian).

Kumar, D., Pornsukarom, S., \& Thakur, S. (2019). Antibiotic Usage in Poultry Production and AntimicrobialResistant Salmonella in Poultry. Food Safety in Poultry Meat Production. Chapter: 3. Publisher: Springer. doi: 10.1007/978-3-030-05011-5_3.

Macer, D. (2019). Ethical Poultry and the Bioethics of Poultry Production The Journal of Poultry Science, 56(2), 79-83. doi: 10.2141/jpsa.0180074.

Udo, H.M.J., Asgedom, A.H., \& Viets, T.C. (2006). Modeling the impact of interventions in village poultry systems. Agricultural Systems, 88(2-3), 255-269. doi: 10.1016/j.agsy.2005.04.001.

Zinchenko, E.V., Panin, A.N., \& Panin, V.A. (2003). Prakticheskie aspekty primenenij probiotikov. Veterinarnyj konsul'tant, 3, 12-14 (in Russian). 